\title{
Mechanisms of stress avoidance and tolerance by plants used in phytoremediation of heavy metals
}

\author{
Anna Małachowska Jutsz*, Anna Gnida \\ Silesian University of Technology \\ Department of Environmental Biotechnology, Poland \\ ${ }^{*}$ Corresponding author's e-mail: anna.malachowska-jutsz@kbs.ise.polsl.pl
}

\begin{abstract}
Keywords: phytoremediation, soil, heavy metals, stress avoidance, stress tolerance
Abstract: Heavy metal pollution of soil is a significant environmental problem and has a negative impact on human health and agriculture. Phytoremediation can be an alternative environmental treatment technology, using the natural ability of plants to take up and accumulate pollutants or transform them. Proper development of plants in contaminated areas (e.g. heavy metals) requires them to generate the appropriate protective mechanisms against the toxic effects of these pollutants. This paper presents an overview of the physiological mechanisms of stress avoidance and tolerance by plants used in phytoremediation of heavy metals.
\end{abstract}

\section{Introduction}

Natural sources of heavy metal pollution associated with migration and circulation of metals in the environment are associated with such processes as volcanic eruptions, weathering of rocks, forest fires, and evaporation from the surface of the oceans. However, more important is the role of the processes related to human activities resulting from rapid development of civilization (anthropogenic sources of heavy metals). Metals introduced into the environment undergo a variety of processes.

Metals in the soil may have various forms, have a high ability to form sparingly soluble salts and oxides, are adsorbed on the surface of minerals and may be bind with organic acids and humic substances. This is conducive to a long period of residual metals in the soil, and the time of its removal, e.g. by water leaching, may be up to several hundred years. In contrast to organic substances, heavy metals do not undergo decomposition. Heavy metals cannot be destroyed biologically; they can only be transformed from one oxidation state or organic compound to another. Remediation of soil contaminated with heavy metals is more difficult than the remediation of other contaminations (De Jing et al. 2007). Plants are the most important link in the food chain resulting from the transfer of metals from soil to animal organisms. The increased content of heavy metals in soils pose a real danger of penetration into the plant, which in turn means turning metals into food chain of the ecosystem. Heavy metals can easily get from the surface layers of soil into the plants and then to each link in the food chain, causing carcinogenic and mutagenic effects in living organisms. The accumulation is significantly higher in the walls and cell membranes, resulting in inhibition of proper growth. Metal toxicity depends not only on its concentration in the environment, but also on their biochemical role in metabolic processes and the mechanisms of absorption, accumulation and excretion by living organisms. Ability of heavy metals to penetrate into higher plants depends on the soil properties and the conditions prevailing in the environment as well as physico-chemical form in which the element occurs. Usually edible parts of the plant, roots and leaves, have an ability of increased accumulation of heavy metals. From this it follows that the carrot, radish, beetroot, parsley and lettuce will have a greater degree of metal contamination than plants whose fruits are edible. Plants also have developed a system for selective accumulation of trace elements from the surrounding environment. Some plants possess a predisposition to accumulate certain trace elements. Since contamination of soils and water with toxic heavy metals is a serious environmental problem, therefore effective remediation methods are necessary. Physical and chemical methods for cleanup and restoration of heavy metal-contaminated soils have serious limitations, such as high cost, irreversible changes in soil properties, destruction of native soil microflora and creation of secondary pollution problems. In contrast, phytoremediation is a better solution to the problem. It is a technology for treatment of the environment (soil, groundwater and surface water, sediments and air), using the natural ability of plants to collect and accumulate unwanted substances or cause their degradation and transformation (Cunningham and Berti 1993, Cunningham and Ow 1996, McGrath et al. 2001, Garbisu et al. 2002, Kamnev 2003, Małachowska-Jutsz et al. 2011).

This technology is based on such properties of certain plants as:

- tolerance to high concentrations of toxic compounds,

- assimilation, accumulation and metabolism of toxic substances in plant organelles,

- conversion of toxic substances present in the environment into non-toxic compounds. 
Phytoremediation is a method, which has great potential for application; its greatest advantage is low cost (even 1000-fold cheaper in comparison with conventional methods). The area of the European Union is approx. 52 million hectares, of which $16 \%$ are contaminated. The north-western part of Europe and areas around the urban agglomerations are the most polluted. It is estimated that over the next 20-25 years, the EU will spend about 100 billion euros for the treatment of the most degraded areas. These data indicate the need to intensify research on phytoremediation, which is cheap and alternative method of land treatment.

The aim of the study was a brief presentation of avoidance mechanisms and stress tolerance mechanisms in plants related to the excessive presence of heavy metals based on the available literature data. This paper summarizes the strategies of metal inactivation or immobilization, strategies of absorption limitation and transformation of metals by plants. This review article comprehensively discusses the background, concepts and future trends in phytoremediation of heavy metals.

\section{Phytoremediation of heavy metal contaminated soil}

Depending on the nature of the biological processes used in the environmental treatment the following types of phytoremediation may be distinguished: phytoextraction, rhizofiltration, phytostabilisation, phytodegradation, rhizodegradation or phytoevaporation. Phytoextraction, phytostabilisation, rhizofiltration and phytoevaporation are usually used for treatment of soil contaminated with heavy metals (HM). Table 1 presents selected examples of field studies performed while phytoremediation of soil contaminated with one or more heavy metals. The most popular type of phytoremediation is phytoextraction, sometimes combined with phytostabilization.

\section{Phytoextraction}

Phytoextraction, also called phytoaccumulation, refers to the uptake and translocation of metal contaminants in the soil by plant roots into above-ground components of the plants. Certain plants, called hyperaccumulators, absorb unusually large amounts of metals compared to other plants and the ambient metals concentration. Natural metal hyperaccumulators are plants that can accumulate and tolerate greater metal concentrations in shoots than those usually found in non-accumulators, without visible symptoms. Examples of commonly reported hyperaccumulators are given in Table 2 (Padmavathiamma and Li 2007).

The success of phytoextraction depends primarily on the choice of the plant, which should have a high tolerance to high concentrations of heavy metals and a substantial degree of HM accumulation, as well as a high degree of movement of metals from roots to parts exposed to air. A very important feature of a plant used for phytoextraction is the abundant production of biomass and a high cut top for easy harvesting. Phytoextraction efficiency is measured by the accumulation of the metal per unit of mass, thus plants that produce a large amount of biomass, such as crop plants (e.g. Brassica juncea (L.) Czern.) may be an alternative to a hyper-accumulators (Kumar et al. 1995, Bricker et al. 2001, Lasat 2002, Tomović et al. 2013).

\section{Rhizofiltration}

Rhizofiltration is a type of phytoremediation that uses plant roots to absorb, concentrate and precipitate contaminants present in the soil through the plant root system into the harvestable parts of the roots and above-ground shoots (Verma et al. 2006, Lee et al. 2010). The plants are raised hydroponically and transplanted into metal-polluted water where they absorb and concentrate the metals in their roots and shoots. Root exudates and changes in rhizosphere $\mathrm{pH}$ may also cause metals to precipitate onto root surfaces. Roots or whole plants are harvested for disposal after they become saturated with the metal contaminants (Padmavathiamma and Li 2007). This method is mainly used to remove such heavy metals as lead, cadmium, zinc and uranium isotopes (mass number of $230,234,235$, and 238 , respectively) from contaminated groundwater.

\section{Phytostabilisation}

The next course of action to be taken in the case of phytoremediation of soil contaminated with heavy metals is phytostabilisation. Certain plant species are used to immobilise the contaminants in the soil by absorption and accumulation by roots, adsorption on the surface of roots, or precipitation in the zone adjacent to the plant roots. The phytostabilisation uses abilities of exudates of some plant roots for reduction in the bio-availability of toxic substances (Cheraghi et al. 2011) as the primary purpose of phytoremediation is to prevent the migration of metals in the environment. Root exudates may act in two ways: toxic metal ions precipitate as insoluble salts (e.g. lead in the form of lead phosphate) or reduce the harmful ions (such as $\mathrm{CrO}_{4}^{2-}$ and $\mathrm{CrO}_{7}^{2-}$ to $\mathrm{Cr}^{3+}$ ) by changing the soil redox (reduction-oxidation) potential. Plants used in phytostabilisation should have an extensive root system and a low degree of metal translocation from roots to shoots (for example the grass studied by a group of British researchers (Wong and Bradshaw 2002) - Agrostis teniuis sp. Goginan and Parys and Festuca rubra sp. Merlin). There are several parameters that predestine some plants to a particular technique. Biological absorption coefficient (BAC) is the ratio of an element concentration in plants to its concentration in soil. Bio-concentration factor $(\mathrm{BCF})$ is a ratio of metal concentration in plant roots to its concentration in soil. Translocation factor (TF) is a metal concentration ratio of plant shoots to roots. Plants with a high biological absorption coefficient (BAC > 1) are suitable for phytoextraction. Plants with a high bio-concentration factor $(\mathrm{BCF}>1)$ and low translocation factor $(\mathrm{TF}<1)$ have the potential for phytostabilisation (Yoon et al. 2006).

\section{Phytoevaporation}

Phytoevaporation is associated with the phenomena of contaminants assimilation and transpiration by a plant, and its further release into the atmosphere in the same or modified form. This method is applicable for treatment of soils and water contaminated with such inorganic compounds as arsenic, mercury, selenium and their volatile derivatives (Zayed et al. 1998). The best-known example of phytoevaporation is remediation of soil and groundwater contaminated with selenium. Selenium is taken up by plants in the form of soluble ions $\mathrm{SeO}_{4}{ }^{2-}$ and $\mathrm{SeO}_{3}{ }^{2-}$ and secreted in the form of dimethyl selenide (de Souza et al. 1999). Phytoevaporation of 
Table 1. Selected phytoremediation field studies (based on: Green and Hoffnagle 2004)

\begin{tabular}{|c|c|c|c|c|}
\hline Country & Mechanism & Contaminant & Plant & Reference \\
\hline USA & PhExt ${ }^{1}$ & $\begin{array}{l}\text { cadmium } \\
\text { lead } \\
\text { zinc }\end{array}$ & Festuca aerundinacea & $\begin{array}{l}\text { MSE } 2001 \\
\text { MSE } 2004\end{array}$ \\
\hline USA & $\mathrm{PhStb}^{2}$ & $\begin{array}{l}\text { lead } \\
\text { zinc } \\
\text { cadmium }\end{array}$ & $\begin{array}{l}\text { Mix of herbaceous species: Western } \\
\text { wheat grass }\end{array}$ & Brown and Chaney 2000 \\
\hline Poland & PhExt ${ }^{1}$ & $\begin{array}{l}\text { cadmium } \\
\text { lead } \\
\text { zinc }\end{array}$ & $\begin{array}{l}\text { Brassica sp, Sinapis alba, Helianthus } \\
\text { sp, Ricinus communis, Zea mays }\end{array}$ & $\begin{array}{l}\text { Institute for Ecology } \\
\text { of Industrial Areas } 1998\end{array}$ \\
\hline Switzerland & PhExt ${ }^{1}$ & $\begin{array}{l}\text { cadmium } \\
\text { copper } \\
\text { zinc }\end{array}$ & Basket willow (Salix viminalis) & Hammer et al. 2003 \\
\hline Canda & PhExt ${ }^{1}$ & $\begin{array}{l}\text { lead } \\
\text { copper }\end{array}$ & $\begin{array}{l}\text { Garden Pea (Pisum sativum) and } \\
\text { Indian Mustard (Brassica juncea) }\end{array}$ & Environment Canada 2000 \\
\hline USA & $\mathrm{RhDg}^{3}$ & diesel fuel, lead, TPH & $\begin{array}{l}\text { Bermuda grass, rye grass, white } \\
\text { clover, tall fescue }\end{array}$ & Banks et al. 1998 \\
\hline USA & $\mathrm{PhStb}^{2} \mathrm{PhExt}^{1}$ & $\begin{array}{l}\text { lead } \\
\text { zinc } \\
\text { cadmium }\end{array}$ & Hybrid poplars & Pierzynski et al. 2002a \\
\hline USA & PhExt $^{1}$ & lead & Indian mustard, sunflower & Blaylock 2000 \\
\hline Switzerland & PhExt ${ }^{1}$ & $\begin{array}{l}\text { cadmium } \\
\text { copper } \\
\text { zinc }\end{array}$ & Basket willow (Salix viminalis) & Hammer et al. 2003 \\
\hline USA & PhExt ${ }^{1}$ & $\begin{array}{l}\text { arsenic } \\
\text { sodium }\end{array}$ & Eucalyptus, Tamarisk & Geomatrix 2004 \\
\hline China & PhExt ${ }^{1}$ & $\begin{array}{l}\text { cadmium } \\
\text { lead } \\
\text { zinc }\end{array}$ & Vetiver grass & Chen et al. 2000 \\
\hline USA & $\begin{array}{l}\text { PhExt }^{1} \\
\text { PhStb }^{2}\end{array}$ & lead & $\begin{array}{l}\text { Indian mustard (Brassica juncea) and } \\
\text { sunflower (Helianthus annus) }\end{array}$ & FRTR 2000 \\
\hline USA & PhExt ${ }^{1}$ & lead & $\begin{array}{l}\text { Indian mustard, sunflower, mixed } \\
\text { grasses }\end{array}$ & Rock and Steve 2003 \\
\hline USA & $\mathrm{PhStb}^{2} \mathrm{PhExt}{ }^{1}$ & $\begin{array}{l}\text { cadmium } \\
\text { lead } \\
\text { zinc }\end{array}$ & tall fescue & Pierzynski et al. 2002b \\
\hline China & PhExt ${ }^{1}$ & $\begin{array}{l}\text { zinc } \\
\text { lead } \\
\text { copper } \\
\text { cadmium }\end{array}$ & $\begin{array}{l}\text { Vetiver grass (V. zizanioides), } \\
\text { Sesbiana species (S. sesban, } \\
\text { S. rostrata) }\end{array}$ & Yang et al. 2003 \\
\hline USA & PhExt ${ }^{1}$ & lead & $\begin{array}{l}\text { Indian Mustard (Brassica juncea) and } \\
\text { sunflower }\end{array}$ & US EPA 2001 \\
\hline USA & PhExt ${ }^{1}$ & $\begin{array}{l}\text { cadmium } \\
\text { chromium } \\
\text { vanadium }\end{array}$ & Bush beans (Phaseolus vulgaris) & Martin and Kaplan 1998 \\
\hline
\end{tabular}

${ }^{1}$ phytoextraction; ${ }^{2}$ phytostabilization; ${ }^{3}$ rhizodegradation

mercury is connected with the breeding of transgenic plants (Arabidopsis thaliana) with the insertion of bacterial genes - merA from E. coli (encoding mercury reductase) and merB from Salmonella typhimurium (encoding methylmercury lyase). These enzymes reduce toxic ions $\mathrm{Hg}^{2+}$ to less toxic, volatile metallic mercury $\mathrm{Hg}^{0}$. Despite the attractiveness of the phytoevaporation process (no waste) it poses a major threat to the environment and human life (Cargnelutti et al. 2006). Intake of heavy metals by plants depends mainly on soil $\mathrm{pH}$, redox potential, organic matter content and the presence of other elements. The form of the metal is a very important factor. Free ions are taken the most quickly. Metals enter the interior of the plant cells by diffusion, endocytosis, or with the aid of phytochelatins and metallothioneins characterized by high affinity for heavy metal. After penetration into the cytoplasm the metal ions are bound by the low molecular weight ligands, and then transported to the vacuole, which protects the plant from serious physiological disorders. Plants have evolved 
Table 2. Accumulation of heavy metals by selected plants (Maciak 2003, Padmavathiamma and Li 2007, Boyd 2009)

\begin{tabular}{|l|l|l|l|}
\hline Plant species & Metal & $\begin{array}{l}\text { Metal content in the plant, } \\
\mathrm{mg} / \mathrm{kg} \text { dry mass }\end{array}$ & Reference \\
\hline Thlaspi caerulescens & Zn & $\begin{array}{l}39600 \\
51600 \\
34000\end{array}$ & $\begin{array}{l}\text { Reeves and Brooks 1983 } \\
\text { Cunningham et al. 1997 } \\
\text { Jhee et al. 1999 }\end{array}$ \\
\hline Thlaspi caerulescens & $\mathrm{Cd}$ & $\begin{array}{l}1800 \\
1900\end{array}$ & $\begin{array}{l}\text { Cunningham et al. 1997 } \\
\text { Jiang et al. 2005 }\end{array}$ \\
\hline Thlaspi rotundifolium & $\mathrm{Pb}$ & $8200-8500$ & $\begin{array}{l}\text { Reeves and Brooks 1983 } \\
\text { Blaylock et al. 1997 }\end{array}$ \\
\hline Brassica juncea & $\mathrm{Pb}$ & 16000 & Blaylock et al. 1997 \\
\hline Alyssum murale & $\mathrm{Ni}$ & 30000 & Angle et al. 2003 \\
\hline Berkheya coddii & $\mathrm{Ni}$ & 37000 & Augustyniak et al. 2002 \\
\hline Haumaniastrum robertii & $\mathrm{Co}$ & 10200 & Brooks 1998 \\
\hline Asparagus racemosus & $\mathrm{Se}$ & 14900 & Beath et al. 1937 \\
\hline $\begin{array}{l}\text { Pteris vittata } \\
\text { Berkheya coddii }\end{array}$ & As & 27000 & Wang et al. 2002 \\
\hline
\end{tabular}

a number of mechanisms protecting them from adverse effects of heavy metals presence.

\section{Plants mechanisms of stress avoidance}

Success of phytoremediation depends on specific mechanisms of stress avoidance and stress tolerance in plants resulting from the presence of high concentrations of heavy metals in soil. It also depends on the physico-chemical properties of the soil itself, the form of the metal, as well as the presence of microorganisms, also the mycorrhizal fungi. The most important mechanisms to avoid stress include: synthesis of callose, mycorrhizae, limitation the metal assimilation by the root, the removal of excess metals and binding metal in the cell wall.

\section{Synthesis of callose}

In the plant cell, the earliest defence reaction in the case of heavy metal presence is a synthesis of callose ( $\beta-1,3$ glucan). This polysaccharide is deposited on the outside of the cell membrane, thereby reducing the diffusion of metal ions into the cell. The enzyme, which is involved in the synthesis of callose, is $\beta$-1, 3-glucan synthetase (Wójcik and Tukiendorf 1995, Woźny and Przybył 2004, Miransari 2011).

\section{Mycorrhizae}

Another mechanism, known as mycorrhizae, enables symbiotic relationships between non-pathogenic fungi and bacterial biocenosis of higher plant roots. Mycorrhizae increases survival of plants in harsh conditions by reducing the stress associated with the availability of water and some nutrients (phosphorus), increasing their resistance to pathogens and modifying the structure of the roots and the medium, in which they grow (Liu et al. 2000, Turnau et al. 2002, Miransari 2011, MalachowskaJutsz et al. 2010). Research studies have shown that arbuscular mycorrhizae (AM) fungi are able to alleviate the stress of heavy metals and petroleum substances (Tam 1995, Davies et al. 2001, Turnau and Mesjasz--Przybyłowicz 2003). Janouskova et al. (2006) found that AM fungi are able to alleviate the unfavourable effects of cadmium $(\mathrm{Cd})$ on plant growth by the process of phytostabilisation. AM hyphae were able to accumulate 10-20 times higher rates of $\mathrm{Cd}$ in comparison to plant roots. Małachowska-Jutsz (2010) found that the colonisation of rhizosphere by mycorrhizal fungi had a beneficial effect on plant root growth and development, as well as on the hydrocarbons degradation by accompanying organisms, e.g. efficiency of heavy fractions removal increased 15 times in comparison with control without AM. An important protective mechanism that enables plants to survive in an environment contaminated with heavy metals is immobilisation of metals within the mycelium and inhibition of their movement to plant tissues (Bradley et al. 1982, Dueck et al. 1986, Killham and Firestone 1983, Heggo et al. 1990, Gucwa-Przepiora et al. 2007, Chen et al. 2008, Miransari 2011). Mycorrhizal fungi reduce the penetration of metal into the cells by:

- release of metal chelating agents, such as citric acid and oxalic acid ( $\mathrm{Zn}, \mathrm{Pb}, \mathrm{Cu}, \mathrm{Cd}, \mathrm{Ni}, \mathrm{Mn}$ ), phenolic compounds, siderophores (Fe) and phosphate ions forming insoluble metal salts,

- metal adsorption on the surface of fungal cells by precipitation of sulphides and hydrated iron oxides,

- immobilisation and accumulation inside the different fungal structures including arbuscules, vesicles and hyphae,

- detoxification within the cells - binding by cytoplasm metallothionein and binding by vacuole polyphosphates.

\section{Limitation of the metal assimilation by the roots}

Another defence mechanism is to limit the metal assimilation from the environment by the roots. Literature data (Driouich et al. 2007, Guo et al. 2009, Cai et al. 2011, Miransari 2011, Meier et al. 2012) indicate that in an environment contaminated with heavy metals plant roots secrete a number of substances that can bind ions and limit their assimilation by plants. Among such compounds are organic acids, and substances present in root extracellular matrix composed mainly of e.g. simple sugars, phenols, amino acids and polysaccharide gels. Reduction of the availability of metal ions occurs also through the production of an oxidizing zone around the roots. As 
a result a reduced form of metals are oxidized and become less soluble and therefore less available to plants. Another way to reduce the toxicity of metals is the ability of roots to change the rhizosphere $\mathrm{pH}$. The increased $\mathrm{pH}$ causes a decrease in the availability of metals (Yang et al. 2005, Siwek 2008a, Siwek 2008b, Miransari 2011).

\section{The removal of excess metals}

Another strategy is the ability of plants to remove excess metals in the form of crystals by salt glands of the leaf epidermis. For example, copper, nickel, zinc, iron and manganese can be removed in such a way by the plant Armeria maritima ssp halleri. The removal of metal excess may also be performed through hydathodes (e.g. in Minuartia verna) and ectoderms (e.g. in Silene vulgaris). Metals may also be transported to the ageing leaves and removed along with them. Such a phenomenon has been observed for example in Anthyllis vulnenaria L. ( $\mathrm{Zn}$ ) and Biscutella laevigata L. (Zn). The literature data (BaranowskaMorek 2003, Olko 2009) confirm that heavy metals can also be accumulated in fibres and idioblasts. There are examples of sequestration of lead by Nicotiana tabacum, nickel by Alyssum lesbiactum, cadmium by Brassica juncea (L.) Czern. and zinc by Avicennia marina (Baranowska-Morek 2003, Olko 2009).

\section{Binding metal in the cell wall}

Another plant defence mechanism against the toxic effects of heavy metals is its binding in the cell wall. For some species, $80-95 \%$ of the metal taken up by the cells can be fixed (this particularly applies to ions of lead, copper and zinc). The cell walls are composed of pectins, which contain galacturonic acid molecules and many of the methylated $\left(\mathrm{COOCH}_{3}\right)$ carboxyl groups, hemicelluloses and cellulose. Their dissociation leads to the appearance of negatively charged groups, which are typically saturated with calcium. In the presence of heavy metals $\left(\mathrm{Cd}^{2+}, \mathrm{Pb}^{2+}, \mathrm{Cu}^{2+}\right)$ calcium ions may be competitively replaced by metals cations. In this way, toxic metal ions are immobilised in the cell wall. Phenolic compounds present in a cell wall may act similarly. Under stress conditions induced by the presence of metals, the physical properties of the cell wall can be changed. The amount of transverse bonds between wall constituents - protein molecules, saccharides and phenols is increased. It can also lead to lignification or suberisation of the cell wall, which causes the wall to become more compact and stiffer, and thus less permeable (Woźny and Przybył 2004, Miransari 2011).

\section{Mechanisms of stress tolerance}

In some cases the metal ions may overcome the plant protective barrier and penetrate into their cells. Factors responsible for the rapid and effective detoxification of the metals affect the tolerance of plants to metal. These factors are: binding the metal complexes with different ligands (chelation) and transportation and accumulation of the complexes in vacuoles. These processes take place with the participation of associated proteins, chaperones, phytochelatins, metallothioneins and organic and amino acids (Hall and Williams 2003, Miransari 2011).

\section{Chaperones}

Chaperones are special proteins that transport ions into places in the cell, where they are incorporated into molecules such as enzymes. A relatively well-known example is the binding and transport of copper ions that occurs in the cells of Arabidopsis thaliana. In this case the chaperone $\mathrm{CCH}$ delivers copper ions to the chloroplasts. Another chaperon AtCOX17 conducts the copper atoms to the mitochondrial cytochrome oxidase and cytosolic $\mathrm{Cu} / \mathrm{Zn}$ superoxide dismutase. Its synthesis is a response to the disruption of mitochondrial functioning (Hall and Williams 2003, Woźny and Przybył 2004).

\section{Glutathione}

Glutathione (GSH; $\gamma$-glu-cys-gly) is the most common low molecular weight thiol compound in nature. It occurs in all prokaryotic and eukaryotic cells. GSH is produced by the synthesis of glutamate (Glu), cysteine (Cys) and glycine (Gly) (Meister and Anderson 1983). It is synthesized in two stages and the reactions are catalyzed by g-glutamylcysteine synthetase $(\gamma$-ECS) and glutathione synthetase $(\gamma$-ECS). In bacteria, yeasts, plants and animals GSH inhibits $\gamma$-ECSs through feedback inhibition that was considered as the prime regulation mechanism of the pathway (Meister 1995, Mendoza-Cozatl and Moreno-Sanchez 2006). In plants and some of the yeast cells GSH is the precursor of phytochelatins synthesis. It has a unique structure, because an a-amino group of cysteine is bound to a $\gamma$-carboxy group of glutamate (not $\alpha$-carboxy group as usually), thereby forming an unusual peptide bond (isopeptide bond). This bond protects glutathione against intracellular peptidases. The only enzyme able to break down the structure is positioned on the outer side of the cell membrane, $\gamma$-glutamyl transferase, also called glutathionase (Gilbert 1990).

Another feature of GSH is the presence of a thiol group (-SH) in the structure belonging to a cysteine moiety. The presence of this group is directly associated with its biological function as they are the most reactive chemical groups which are present in the cell (Gilbert 1990). Glutathione is an antioxidant. Its presence determines the detoxification of hydrogen peroxide, organic peroxide and other reactive oxygen forms, as well as exogenous and endogenous electrophilic compounds. The redox potential of the GSSG/GSH fosters reactions between reduced glutathione and oxidized forms of other antioxidants. It has the ability to chelate hazardous metal ions, participates in reconstructing damaged cell components, especially proteins and lipids, and DNA cell membranes (Pastore et al. 2003). In addition, the compound is involved in maintaining the proper redox potential of cells (Cotgreave and Gerdes 1998), which is important in the regulation of intracellular metabolism (Pastore et al. 2003), apoptosis (Hall $1999 \mathrm{a}, \mathrm{b}$ ) and in the growth and differentiation of cells (Poot at al. 1995, Hall 1999).

Gupta et al. (2002) have shown that exposition of plants to cadmium results in increase of cysteine as well as other thiol compounds. This suggests that $\mathrm{Cd}$ activates first step in the GSH biosynthesis, probably synthesis of cysteine. These observations can be used to assess the oxidative stress of plants growing in soils contaminated with cadmium, and perhaps with other heavy metals. Bruns et al. (2001) have shown that after exposure of plants to the $100 \mathrm{mmol} \mathrm{Cd} / \mathrm{L}$ the concentration of GSH significantly increased in the plants cells, as well as cysteine and $\gamma$-glutamyl-cysteine. The authors showed that the complexes $\mathrm{GSH} / \mathrm{Cd}$ are transported to the cytoplasm. It suggests that GSH plays a key role in the detoxification of 
heavy metals during their transport to the cytoplasm. From there they could be downloaded by the vacuole and degraded, and cadmium is accumulated in the form of phosphates.

\section{Metallothioneins}

Tolerance and ability of plant cells to accumulate large amounts of heavy metals is concerned with the presence of proteins that bind metal ions (metallothionein and phytochelatins). Intake of metal ions by the roots and its transport to shoots requires the participation of specific transport proteins (e.g. P-ATPase - subfamily P1B, CDF - Cation Diffusion Facilitator, Nramp - Natural resistance associated macrophage protein, ZIP - Zinc regulated transporter, Iron - regulated transporter-like protein, YSL - Yellow Stripe1-like and family ABC - ATP Binding Cassette). Biotransformation enzymes are required for changing the oxidation state of the elements. Plants do not have enzymes that enable reduction of e.g. mercury ions to gaseous form (Hussein et al. 2007). Metallothioneins (MTs) are cysteine-rich proteins of low molecular weight which bind the metal ions with thiol groups. They are involved in the detoxification of copper and cadmium ions, and buffer the concentration of zinc in the cytoplasm. Probably they also provide zinc ions to zinc-dependent enzymes. They are products of mRNA translation found in animals and plants. MTs play a role in detoxification of heavy metals in animals and fungi, although their exact function is not completely understood (Robinson et al. 1993, Hall 2002). In plants they may participate in metal homeostasis since correlation between MT RNA levels and naturally occurring differences in tolerance to heavy metals in Arabidopsis ecotypes were observed (Murphy and Taiz 1995, Murphy et al. 1997, Guo et al. 2008). Other proposed functions of MTs in plants are: metal detoxification (Domenech et al. 2006, Roosens et al. 2008), senescence (Coupe et al. 1995, Hsieh et al. 1995) and protection against abiotic stress (Zhou et al. 2005). In different organisms, the MT expression correlates with metal concentration what suggests that they can be effective markers of environmental conditions (Morris et al. 1999). Scientists (Morris et al. 1999, Zhu et al. 1999a 1999b, Cobbett and Goldsbrough 2002, Zimeri et al. 2005) report that isolation and characterisation of MTs in model bio-indicator organisms could also contribute to understanding of the biological response to pollutants in the environment.

\section{Phytochelatins}

The principal role of phytochelatins (PC) is transport of divalent metal from the cytoplasm into the vacuole, where in low $\mathrm{pH}$ conditions the PC-metal complex undergoes dissociation, and the metal ions are combined with organic acids (Clemens et al. 1999, Clemens 2006). They take part in maintaining a homeostasis of the divalent ions in the cells which, depending on requirements, can be released from the complexes and used, for example, to produce metalloenzymes (Bar-Ness et al. 1991, Cobbett and Goldsbrough 2002, Hirata et al. 2005, Gasic and Korban 2007a, Gasic and Korban 2007b). Phytochelatins are considered to play a major role in metal detoxification (Le Faucheur et al. 2005). They play role in homeostasis of heavy metals in plants, and this is the mechanism that regulates the metal ions availability in plant cells (Guo et al. 2008). In majority of plants they are composed of three types of amino acids: glutamic acid (Glu), cysteine (Cys) and glycine (Gly). Phytochelatins are small peptides with the general structure ( $\gamma$-Glu-Cys) n-Gly, where $\mathrm{n}$ is from 2 to 11 (usually 2-5). Phytochelatins can be produced enzymatically as a consequence of presence of many metals (Cobbett 2000, Rauser 2000). They are synthesized from reduced glutathione (GSH) and catalysed by phytochelatin synthetase (PCS) (Grill et al. 1989), which is activated by $\mathrm{Cd}^{2+}, \mathrm{Ag}^{+}, \mathrm{Bi}^{3+}, \mathrm{Pb}^{2+}, \mathrm{Zn}^{2+}, \mathrm{Cu}^{2+}, \mathrm{Hg}^{+}$and $\mathrm{Au}^{+}$. They are not encoded by genes directly, but the products of a biosynthetic pathway (reactions 1 to 4 ).

$$
\begin{gathered}
\text { Gly }+ \text { Cys } \rightarrow \text { GCS } \\
\gamma \text {-Glu-Cys }+ \text { Glu } \rightarrow \text { GS } \\
\text { GSH } \rightarrow \text { PCS }^{+ \text {Cd }} \\
\mathrm{PC} \rightarrow \text { PC-Cd } \rightarrow \text { HMT1 vacuole }
\end{gathered}
$$

where GCS - $\gamma$-glutamylcysteine synthetase, GS - GSH synthetase, PCS - phytochelatin synthase, HMT1 - a vacuolar membrane transporter of PC-Cd complexes.

There is number of structural variants of PCs in plants, such as ( $\gamma$-Glu-Cys)n- $\beta$-Ala, $(\gamma$-Glu-Cys)n-Ser, and $(\gamma$-GluCys)n-Glu (Cobbett 2000, Rauser 2000).

Research performed on more than 200 plant species showed their ability to detoxify cadmium and other heavy metals. The mechamism of detoxication was chelation of heavy metals to peptides (Gekeler et al. 1989). Grill et al. (1987) and Le Faurcheur et al. (2005) created a series of heavy metals according to their strength of PCs production. It is as follows: $\mathrm{Cd}>\mathrm{Pb}>\mathrm{Zn}>\mathrm{Sb}>\mathrm{Ag}>\mathrm{Hg}>\mathrm{As}>\mathrm{Cu}>\mathrm{Sn}>\mathrm{Au}>\mathrm{Bi}$. Cadmium is known to be the strongest inducer of $\mathrm{PC}$ in plants and algae (Maitani et al. 1999, Grill et al. 1987).Some heavy metals as $\mathrm{Ni}, \mathrm{Te} \mathrm{W}$ or Se were found not to be able for activation of PC synthesis (Zenk 1996).

\section{Metal binding}

Metal ions present in the cytoplasm can also attach directly to the thiol groups of glutathione and be transported to the vacuole (Zhu et al. 1999a, Miransari 2011). There, the complex undergoes decomposition and the metal ions are bound to phosphates. This mechanism is similar to phytochelatins functioning with such a difference that reduced glutathione is the complexing agent (Dixon et al. 1998, Freeman et al. 2004, Freeman et al. 2005). Organic acids such as malic, citric, oxalic acid can bind metal ions. Metal is associated to an acid molecule through a carboxyl group $(\mathrm{COOH})$ and in this form transported to the vacuole. The complex of acid and metal possesses a form of transport of metal through the xylem vessels. For example, iron is transported in the form of citrate that results in reduction of the binding of the metal by ion-exchange structures. Citric acid is also likely to be the main compound which binds cadmium ions (at low concentration of the element), nickel and zinc. In turn, malic acid binds zinc ions (Singla-Pareek et al. 2006). Histidine is an amino acid involved in metal binding. It forms a complex with the ions, in particular nickel, but also with zinc and copper. In the plant that hyper-accumulates nickel Alyssum lesbiacum the concentration of histidine in xylem juice after exposure to this metal was 36-fold higher. Another amino acid - nicotianamine has an ability to chelate iron ions and copper, and zinc to a lesser extent (Singla-Pareek et al. 2006). 


\section{Plants or metabolic pathways engineering}

Singla-Pareek et al. (2006) reported a novel mechanism of heavy metal tolerance in plants that involved engineering of the glyoxalase pathway. This pathway comprises two steps. One is catalysed by glyoxalase I while the other by glyoxalase II. The engineering strategy has been found to be suitable for improvement of heavy-metal tolerance in transgenic tobacco ( N. tabacum). The glyoxalase transgenics were able to grow, flower, and set normal viable seeds in the presence of $5 \mathrm{mM} \mathrm{ZnCl}{ }_{2}$ without any yield penalty. The concentration of endogenous ions revealed that roots were the major sinks for excess $\mathrm{Zn}$ accumulation while its amount in transgenic plants seeds was negligible. It is suggested that glyoxalase over-expression might confer tolerance to other heavy metals, such as $\mathrm{Cd}$ and $\mathrm{Pb}$. Transgenic plants over-expressing both glyoxalase I and II had reflected better relative tolerance than transgenic plants over-expressing either glyoxalase I or II individually. Biochemical investigations of such transgenics have indicated the control over methylglyoxal (MG) and malodialdehyde (MDA) accumulation under high levels of $\mathrm{Zn}$ exposure. Usage of glutathione biosynthetic inhibitor (buthionine sulphoximine) caused an increase in PCs level and maintenance of $\mathrm{GSH} / \mathrm{GSSG}$ redox ratio in transgenic plants. This provided tolerance to $\mathrm{Zn}$ stress (Singla-Pareek et al. 2006). Depending on the specific features of the plants, they are useful in a particular technique of phytoremediation. Such plants should have a very well developed root system, rapid growth, produce large amounts of biomass, be able to accumulate and tolerate high concentrations of heavy metals (Eapen et al. 2005). None of the many natural phytoremediators meets all of these requirements. Recognition and understanding of the phytoremediation mechanisms enables the obtaining of transgenic specimens that are almost perfect phytoremediators. Thlaspi caerulescens is a plant that is often used in studies focused on the natural resistance of plants to high concentrations of heavy metals. Comparison of its detoxification mechanisms with mechanisms presented by other plants from the cabbage family Thlaspi arvense enabled selection of the genes potentially useful in the designing of plants eligible in phytoremediation. Frequently used transporter genes are genes encoding heavy metals or the heavy metal binding ligands (Milner et al. 2008).

Tolerance and ability of plant cells to accumulate large amounts of heavy metals is concerned with the presence of proteins that bind metal ions (metallothionein and phytochelatins). However, it is possible to create transgenic plants with bacterial genes, since some bacteria have mercury resistance genes typically located in the mer operon. Such operon consists of gene merA coding mercury reductase, gene merB coding lyase of organic derivatives of mercury and genes merP, merT, merC, merE, merG coding enzymes involved in the transport of mercury ions (Milner and Kochian 2008).

\section{Repair of cell damage}

Tolerance of stress caused by toxic heavy metals also relies on the fast and effective repair of damage caused in the cell. Repair functions are helped by the heat shock protein (HSPs), whose expression was first observed in plant cells exposed to high temperatures. They are also synthesized in the case of stress caused by other factors, including heavy metals (SinglaPareek et al. 2006).

\section{Conclusions}

Phytoremediation is environment-friendly and ecologically responsible solar-driven technology with good public acceptance. It is a relatively recent technology and is mostly in research stage. Its research is highly interdisciplinary in nature and requires background knowledge in soil chemistry, plant biology, ecology and soil microbiology as well as environmental engineering. Research is in progress to screen native plants for phytoremediation of heavy metals and to evaluate the effect of different parameters on phytoremediation efficiency. An improved understanding of heavy metal uptake by plants from soil will also help in promoting phytomining - a plant-based eco-friendly mining of metals, which can be used for extraction of metals even from low-grade ores. Phytoextraction of heavy metals is expected to be a commercially viable technology for phytoremediation and phytomining of heavy metals in the future. Plants have evolved a number of mechanisms by which they can survive in soils contaminated with metals. Generally, these mechanisms represent two strategies: avoiding stress and stress tolerance. The first relies on reduction of metal accumulation and prevention of its penetration into a symplast. The stress tolerance mechanisms begin to function when the metal crosses the cell membrane. The most important role in the whole process is that of the plants and rhizosphere micro-organisms. Without their participation the phytoremediation process does not proceed. There are a number of species in nature which are capable of growing in soils contaminated with high concentrations of heavy metals. The role of rhizosphere microorganisms in the resistance of plants to stress caused by the presence of heavy metals cannot be ignored. In recent years transgenic plants have become more and more popular and used in phytoremediation processes. Research is being conducted to genetically modify some suitable plants for better phytoremediation of heavy metals and other xenobiotics. Studies are also being done to identify and characterize different proteins involved in cross-membrane transport and vacuolar sequestration of heavy metals. Advancement and achievements in such molecular studies will greatly help in understanding the mechanism and enhancing the efficiency of phytoremediation. However, the problem is not just the acquisition of such plants, but also the need to change the existing legislation and overcome the reluctance of public opinion to accept transgenic organisms. Despite the obvious advantages such as: low cost of the process, the minimum level of violations of environmental homeostasis, visual attractiveness, and phytoremediation, each technology has also disadvantages. The most important disadvantage is the long-lasting treatment, the limited scope of the roots, too high concentrations of metals which can cause bending of plants. Therefore, it is necessary to conduct intensive research on phytoremediation which may result in elimination of its limitations in the near future and then phytoremediation will become the primary method of treatment of soil.

\section{References}

Angle, J.S., Baker, A.J.M., Whiting, S.N. \& Chaney, R.L. (2003). Soil moisture effects on uptake of metals by Thlaspi, Alyssum, and Berkheya, Plant Soil, 256, pp. 325-332.

Augustyniak, M., Mesjasz-Przybylowicz, J., Nakonieczny, M., Dybowska, M., Przybylowicz, W. \& Migula, P. (2002). 
Food relations between Chrysolina pardalina and Berkheya coddii, a nickel hyperaccumulator from South African ultramafic outcrops, Fresenius Environmental Bulletin, 11, pp. 85-90.

Banks, M.K., Schwab, A.P., Govindaraju, R.S., Lewis, S., Rathbone, K. \& Kulakow, P. (1998). Phytoremediation of soil contaminated with hazardous chemicals: a field assessment at the Craney Island fuel terminal. In: Final Report of DOD AATDF project. Rice University Publishing, USA 1998.

Baranowska-Morek, A. (2003). Mechanisms of plants tolerance to toxic influence of heavy metals, Kosmos, 52 (2-3), pp. 283-298. (in Polish)

Bar-Ness, E., Chen, Y., Hadar, Y., Marchner, H. \& Romheld, V. (1991). Siderophores of Pseudomonas putida as an iron source for dicot and monocot plants, Plant Soil, 130 (1-2), pp. 231-241.

Beath, O.A., Eppsom, H.F. \& Gilbert, G.S. (1937). Selenium distribution in and seasonal variation of vegetation type occurring on seleniferous soils, Journal of American Pharmacists Association, 26, pp. 394-405.

Blaylock, M.J., Salt, D.E., Dushenkov, S., Zakharova, O., Gussman, C., Kapulnik, Y., Ensley, B. \& Raskin, I. (1997). Enhanced accumulation of $\mathrm{Pb}$ in Indian mustard by soil-applied chelating agents, Environmental Science \& Technology, 31 (3), pp. 860-865.

Boyd, R.S. (2009). High-nickel insects and nickel hyperaccumulator plants: A review, Insect Science, 16, pp. 19-31.

Bradley, R., Burt, A.J. \& Read, D.J. (1982). The biology of mycorrhizae in the Ericaceae. VIII. The role of mycorrhizal infection in heavy metal resistance, New Phytologist, 91 (2), pp. 197-202.

Bricker, T.J., Pichtel, J., Brown, H.J. \& Simmons, M. (2001). Phytoextraction of $\mathrm{Pb}$ and $\mathrm{Cd}$ from superficial soil: effects of amendments and croppings, Journal of environmental science and health. Part A, Toxic/hazardous substances \& environmental engineering, 36, pp. 1597-1610.

Brooks, R.R. (ed.) (1998). Plants that hyperaccumulate heavy metals. CAB International, pp. 384, Wallingford 1998.

Brown, S.L. \& Chaney, R.L. (2000). Combining residuals to achieve specific soil amendment objectives, In: Bartels J. (ed.) Land Application of Agricultural, Industrial and Municipal By-Products. Soil Science Society of America, WI, pp. 343-360, Madison 2000.

Bruns, I., Sutter, K., Menge, S., Neumann, D. \& Krauss, G.J. (2001) Cadmium lets increase the glutathione pool in bryophytes, Journal of Plant Physiology, 158, pp. 79-89.

Cai, M.Z., Wang, F.M., Li, R.F., Zhang, S.N., Wang, N. \& Xu, G.D. (2011). Response and tolerance of root border cells to aluminum toxicity in soybean seedlings, Journal of Inorganic Biochemistry, 105, pp. 966-971.

Cargnelutti, D., Tabaldi, L.A., Spanevello, R.M., de Oliveira Jucoski, G., Battisti, V., Redin, M., Linares, CEB, Dressler, V.L., de Moraes Flores, E.M., Nicoloso, F. \& Morsch, V.M. (2006). Mercury toxicity induces oxidative stress in growing cucumber seedlings, Chemosphere, 65, pp. 999-1006.

Chen, B., Roos, P., Zhu, Y.G. \& Jakobsen, I. (2008). Arbuscular mycorrhizas contribute to phytostabilization of uranium in uranium mining tailings, Journal of Environmental Radioactivity, 99, pp. 801-810.

Chen, H.M., Zheng, C.R., Tu, C. \& Shen, Z.G. (2000). Chemical methods and phytoremediation of soil contaminated with heavy metals, Chemosphere, 41, pp. 229-234.

Cheraghi, M., Lorestani, B., Khorasani, N., Yousefi, N. \& Karami, M. (2011). Findings on the phytoextraction and phytostabilization of soils contaminated with heavy metals, Biological Trace Element Research, 144, pp. 1133-1141.
Clemens, S., Kim, E.J., Neumann, D. \& Schroeder, J.I. (1999). Tolerance to toxic metals by a gene family of phytochelatin synthases from plants and yeast, EMBO Journal, 18, pp. 3325-3333.

Clemens, S. (2006). Toxic metal accumulation, responses to exposure and mechanisms of tolerance in plants, Biochimie, 88, pp. 1707-1719.

Cobbett, C.S. (2000). Phytochelatin biosynthesis and function in heavy metal detoxification, Current Opinion in Plant Biology, 3, pp. 211-216.

Cobbett, C. \& Goldsbrough, P. (2002). Phytochelatins and metallothioneins: roles in heavy metal detoxification and homeostasis, Annual Review of Plant Biology, 53, pp. 159-182.

Cotgreave, I.A. \& Gerdes, R.G. (1998) Recent trends in glutathione biochemistry - glutatione-protein interactions: a molecular link between oxidative stress and cell proliferation? Biochemical and Biophysical Research Communications, 242, pp. 1-9.

Coupe, S.A., Taylor, J.E. \& Roberts, J.A. (1995) Characterization of an mRNA encoding a metallothionein-like protein that accumulates during ethylene-promoted abscission of Sambucus nigra L., Planta, 197, pp. 442-447.

Cunningham, S.D. \& Berti, W.R. (1993). Remediation of contaminated soils with green plants: an overview, In Vitro Cellular \& Developmental Biology, 29 (4), pp. 207-212.

Cunningham, S.D. \& Ow, D.W. (1996). Promises and prospects of phytoremediation, Plant Physiology, 110 (5), pp. 715-719.

Cunningham, S.D., Shann, J.R., Crowley, D.E. \& Anderson, T.A. (1997). Phytoremediation of contaminated water and soil. In: Kruger EL, Anderson TA, Coats JR (ed.) Phytoremediation of soil and water contaminants. ACS Symposium series 664. American Chemical Society, pp. 2-19, Washington DC 1997.

Davies, F.T.Jr., Puryear, J.D. \& Newton, R.J. (2001). Mycorrhizal fungi enhance accumulation and tolerance of chromium in sunflower (Helianthus annuus), Journal of Plant Physiology, 158 (6), pp. 777-786.

De Jing, Y., He, Z. \& Yang, X. (2007). Role of soil rhizobacteria in phytoremediation of heavy metal contaminated soils, Journal of Zhejiang University SCIENCE B, 8, pp. 192-207.

Dixon, D.P., Cummins, L., Cole, D.J. \& Edwards, R. (1998). Glutathione-mediated detoxification systems in plants, Current Opinion in Plant Biology, 1, pp. 258-266.

Domenech, J., Mir, G., Huguet, G., Capdevila, M., Molinas, M. \& Atrian, S. (2006). Plant metallothionein domains: functional insight into physiological metal binding and protein folding, Biochimie, 88, pp. 583-593.

Driouich, A., Durand, C. \& Vicre-Gibouin, M. (2007). Formation and separation of root border cells. Review, Trends in Plant Science, 12 (1), pp. 14-19.

Dueck, T.A., Visser, P., Ernst, W.H.O. \& Schat, H. (1986). Vesicular arbuscular mycorrhizae decrease zinc toxicity to grasses in zinc polluted soil, Soil Biology \& Biochemistry, 18 (3), pp. 331-333.

Eapen, S. \& D'souza, S. (2005). Prospects of genetic engineering of plants for phytoremediation of toxic metal, Biotechnology Advances, 23, pp. 97-114.

Freeman, J.L., Persans, M.W., Nieman, K., Albrecht, C., Peer, W., Pickering, I.J. \& Salt, D.E. (2004). Increased glutathione biosynthesis plays a role in nickel tolerance in Thlaspi nickel hyperaccumulators, Plant Cell, 16, pp. 2176-2191.

Freeman, J.L., Garcia, D., Kim, D., Hopf, A. \& Salt, D.E. (2005). Constitutively elevated salicylic acid signals glutathione-mediated nickel tolerance in Thlaspi nickel hyperaccumulators, Plant Physiology, 137, pp. 1082-1091. 
FRTR (2000). Phytoremediation at the open burn and open detonating area. In: Abstracts of Remediation Case Studies, Volume 4. Ensign-Bickford Company, Simsbury, USA 2000.

Garbisu, C., Hernandez-Allica, J., Barrutia, O., Alkorta, I. \& Becerril, J.M. (2002). Phytoremediation: a technology using green plants to remove contaminants from polluted areas, Reviews on Environmental Health, 17 (3), pp. 173-188.

Gasic, K. \& Korban, S.S. (2007a). Expression of Arabidopsis phytochelatin synthase in Indian mustard (Brassica juncea) plants enhances tolerance for $\mathrm{Cd}$ and $\mathrm{Zn}$, Planta, 225, pp. $1277-1285$.

Gasic, K. \& Korban, S.S. (2007b). Transgenic Indian mustard (Brassica juncea) plants expressing an Arabidopsis phytochelatin synthase (AtPCS1) exhibit enhanced As and Cd tolerance, Plant Molecular Biology, 64, pp. 361-369.

Gekeler, W., Grill, E., Winnacker, E.-L. \& Zenk, M.H. (1989). Survey of the plant kingdom for the ability to bind heavy metals through phytochelatins, Zeitschrift für Naturforschung, 44c, pp. 361-369.

Geomatrix Consultants, Inc. (prepared in association with S.S. Papadopulos and Associates Inc.) (2004). Five Year Status Report, East Palo Alto, USA 2004.

Gilbert, H.F. (1990). Molecular and cellular aspects of thiol-disulfide exchange, Advances in Enzymology and Related Areas of Molecular Biology, 63, pp. 69-172.

Green, C. \& Hoffnagle, A. (2004). Phytoremediation field studies database for chlorinated solvents, pesticides, explosives, and metals. Environmental Protection Agency Office of Superfund Remediation and Technology Innovation, Washington, USA 2004.

Grill, E., Löffler, S., Winnacker, E.L. \& Zenk, M.H. (1989). Phytochelatins, the heavy metals-binding peptides of plants, are synthesized from glutathione by a specific $\gamma$-glutamilcysteine dipeptidyl transpeptidase (phytochelatin synthase), Proceedings of the National Academy of Sciences, USA, 86, pp. 6838-6842.

Grill, E., Winnackert, E. \& Zenk, M.H. (1987). Phytochelatins, a class of heavy-metal-binding peptides from plants, are functionally analogous to metallothioneins, Proceedings of the National Academy of Sciences, USA, 84, pp. 439-443.

Gucwa-Przepiora, E., Malkowski, E., Sas-Nowosielska, A., Kucharski, R., Krzyzak, J., Kita, A. \& Romkense, O. (2007). Effect of chemophytostabilization practices on arbuscular mycorrhiza colonization of Deschampsia cespitosa ecotype Warynski at different soil depths, Environmental Pollution, 150, pp. 338-346.

Guo, W.J., Meetam, M. \& Goldsbrough, P. (2008). Examining the specific contributions of individual Arabidopsis metallothioneins to copper distribution and metal tolerance, Plant Physiology, 164 (4), pp. 1697-1706.

Guo, B., Liang, Y. \& Zhu, Y. (2009). Does salicylic acid regulate antioxidant defense system, cell death, cadmium uptake and partitioning to acquire cadmium tolerance in rice?, Journal of Plant Physiology, 166, pp. 20-31.

Gupta, D.K., Tohoyama, H., Joho, M. \& Inouhe, M. (200) Possible roles of phytochelatins and glutathione metabolism in cadmium tolerance in chickpea roots, Journal of Plant Research, 115, pp. 429-437.

Hall, A.G. (1999a). Glutathione and the regulation of cell death, Advances in Experimental Medicine and Biology, 457, pp. 199-203.

Hall, A.G. (1999b). The role of glutathione in the regulation of apoptosis, European Journal of Clinical Investigation, 29, pp. 238-245.

Hall, J.L. (2002). Cellular mechanisms for heavy metal detoxification and tolerance, Journal of Experimental Botany, 53, pp. 1-11.
Hall, J.L. \& Williams, L.E. (2003). Transition metal transporters in plants, Journal of Experimental Botany, 54, pp. 2601-2613.

Hammer, D., Kayser, A. \& Keller, C. (2003). Phytoextraction of Cd and $\mathrm{Zn}$ with Salix viminalis in field trials, Soil Use and Management, 19, pp. 187-192.

Heggo, A., Angle, J.S. \& Chaney, R.L. (1990). Effect of vesicular-arbuscular mycorrihyza fungi on heavy metal uptake by soybeans, Soil Biology \& Biochemistry, 22 (6), pp. 865-869.

Hirata, K., Tsuji, N. \& Miyamoto, K. (2005). Biosynthetic regulation of phytochelatins, heavy metal-binding peptides, Journal of Bioscience and Bioengineering, 100, pp. 593-599.

Hsieh, H.M., Liu, W.K. \& Huang, P.C. (1995). A novel stress-inducible metallothionein-like gene from rice, Plant Molecular Biology, 28, pp. 381-389.

Hussein, H.S., Ruiz, O.N., Terry, N. \& Daniell, H. (2007). Phytoremediation of mercury and organomercurials in chloroplast transgenic plants: enhanced root uptake, translocation to shoot and volatilization, Environmental Science \& Technology, 41, pp. 8439-8446.

Institute for Ecology of Industrial Areas (1998). Final Report for Bytom, Poland laboratory and site phytoremediation project. Institute for Ecology of Industrial Areas, Katowice, Poland 1998.

Janouskova, M., Pavlikowa, D. \& Vosatka, M. (2006). Potential contribution of arbuscular mycorrhiza to cadmium immobilisation in soil, Chemosphere, 65, pp. 1959-1965.

Jhee, E.M., Dandridge, K.L., Christy, A.M. \& Pollard, A.J. (1999). Selective herbivory on low-zinc phenotypes of the hyperaccumulator Thlaspi caerulescens (Brassicaceae), Chemoecology, 9, pp. 93-95.

Jiang, R.F., Ma, D.Y., Zhao, F.J. \& McGrath, S.P. (2005). Cadmium hyperaccumulation protects Thlaspi caerulescens from leaf feeding damage by thrips (Frankliniella occidentalis), New Phytologist, 167, pp. 805-914.

Kamnev, A.A. (2003). Phytoremediation of heavy metals: An overview. In: Fingerman, M, Nagabhushanam, R. (ed). Recent Advances in Marine Biotechnology 8: Bioremediation. Science Publishers Inc, Enfield, USA, pp. 269-317.

Killham, K. \& Firestone, M.K. (1983). Vesicular arbuscular mycorrhizal mediation of grass response to acidic and heavy metal deposition, Plant Soil, 72 (1), pp. 39-48.

Kumar, P.B.A., Dushenkov, V., Motto, H. \& Raskin, I. (1995). Phytoextraction: the use of plants to remove heavy metals from soils, Environmental Science \& Technology, 29 (5), pp. $1232-1238$.

Lasat, H.A. (2002). Phytoextraction of toxic metals: a review of biological mechanisms, Journal of Environmental Quality, 31 (1), pp. 109-120.

Le Faucheur, S., Behra, R. \& Sigg, L. (2005). Phytochelatin induction, cadmium accumulation, and algal sensitivity to free cadmium ion in Scenedesmus vacuolatus, Environmental Toxicology and Chemistry, 24 (7), pp. 1731-1737.

Lee, M. \& Yang, M. (2010). Rhizofiltration using sunflower (Helianthus annuus L.) and bean (Phaseolus vulgaris L. var. vulgaris) to remediate uranium contaminated groundwater, Journal of Hazardous Materials, 173, pp. 589-596.

Liu, A., Hamel, C., Hamilton, R.I., Ma, .B.L. \& Smith, D.L. (2000). Acquisition of $\mathrm{Cu}, \mathrm{Zn}, \mathrm{Mn}$ and $\mathrm{Fe}$ by mycorrhizal maize (Zea mays L.) grown in soil at different $\mathrm{P}$ and micronutrient levels, Mycorrhiza, 9 (6), pp. 331-336.

Maciak, F. (2003). The protection and restoration of the environment, SGGW Ed., Warsaw 2003. (in Polish)

Maitani, T., Kubota, H., Sato, K. \& Yamata, T. (1999). Phytochelatins (class III metallothioneins) and their desglycyl peptides induced by cadmium in root cultures of Rubia tinctorum L. Advances in Life Sciences, Metalothionein, 4, pp. 201-205. 
Małachowska-Jutsz, A. (2008). Plant mycorrhization effectiveness of phytoremediation of soil polluted with hydrocarbons, Zeszyty Naukowe Politechniki Ślaskiej, 1782. (in Polish)

Małachowska-Jutsz, A., Kalka, J., Baczyński, T. (2010). Influence of mycorrhizal fungi on remediation of soil contaminated by petroleum hydrocarbons, Fresenius Environmental Bulletin, 19(12b), pp. 1-7.

Małachowska-Jutsz, A., Rudek, J., Janosz, W. (2011). The effect of ribwort (Plantago lanceolata) and its myrorrhizas on the growth of microflora in soil contaminated with used engine oil, Archives of Environmental Protection, 37(1), pp. 99-113.

Martin, H.W. \& Kaplan, D.I. (1998). Temporal changes in cadmium, thallium, and vanadium mobility in soil and phytoavailability under field conditions, Water, Air, \& Soil Pollution, 101, pp. 399-410.

McGrath, S.P., Zhao, F.J. \& Lombi, E. (2001). Plant and rhizosphere processes involved in phytoremediation of metalcontaminated soils, Plant Soil, 232 (1-2), pp. 207-214.

Meier, S., Alvear, M., Borie, F., Aguilera, P., Ginocchio, R. \& Cornejo, P. (2012). Influence of copper on root exudate patterns in some metallophytes and agricultural plants, Ecotoxicology and Environmental Safety, 75, pp. 8-15.

Meister, A. \& Anderson, M.E. (1983). Glutathione, Annual Review of Biochemistry, 52, pp. 711-760.

Meister, A. (1995). Glutathione metabolism, Methods in Enzymology, 251, pp. 3-13.

Mendoza-Cozatl, D.G., Moreno-Sanchez, R. (2006). Control of glutathione and phytochelatin synthesis under cadmium stress. Pathway modeling for plants, Journal of Theoretical Biology, 238, pp. 919-936.

Milner, M.J. \& Kochian, L.V. (2008). Investigating heavy-metal hyperaccumulation Thaspi caerulescens as model system, Annals of Botany, 102, pp. 3-13.

Miransari, M. (2011). Hyperaccumulators, arbuscular mycorrhizal fungi and stress of heavy metals, Biotechnology Advances, 29, pp. 645-653.

Morris, C.A., Nicolaus, B., Sampson, V., Harwood, J.L. \& Kille, P. (1999). Identification and characterization of a recombinant metallothionein protein from a marine alga Fucus vesiculosus, Biochemical Journal, 338, pp. 553-560.

MSE Technology Applications, Inc. (2001). Interim report for the revegetation of mining waste using organic amendments and the potential for creating attractive nuisances for wildlife demonstration project. MWTP Activity III, Project 23 Report prepared by MSE for the U.S. EPA's National Risk Management Laboratory (NRMRL), Cincinnati, OH and U.S. DOE: National Energy Technology Laboratory (NETL), Pittsburgh, PA as document number MWTP-189, July 2001.

MSE Technology Applications, Inc (2004) Final Report for the revegetation of mining waste using organic amendments and the potential for creating attractive nuisances for wildlife demonstration project. MWTP Activity III, Project 23 Report prepared by MSE for the U.S. EPA's National Risk Management Laboratory (NRMRL), Cincinnati, OH and U.S. DOE: National Energy Technology Laboratory (NETL), Pittsburgh, PA as document number MWTP-239, March 2004.

Murphy, A. \& Taiz, L. (1995). Comparison of metallothionein gene expression and non-protein thiols in 10 Arabidopsis ecotypes correlation with copper tolerance, Plant Physiology, 109, pp. 1-10.

Murphy, A., Zhou, J., Goldsbrough, P.B. \& Taiz, L. (1997). Purification and immunological identification of metallothioneins 1 and 2 from Arabidopsis thaliana, Plant Physiology, 113, pp. 1293-1301.
Olko, A. (2009). Physiological aspects of plant tolerance to heavy metals, Kosmos, 58 (1-2), pp. 221-228. (in Polish)

Padmavathiamma, P.K. \& Li, L.Y. (2007). Phytoremediation Technology, Hyper-accumulation metals in plants, Water, Air, \& Soil Pollution, 184, pp. 105-126.

Pastore, A., Federici, G., Bertini, E. \& Piemonte, F. (2003) Analysis of glutatione: implication in redox and detoxification, Clinica Chimica Acta, 333, pp. 19-39.

Pierzynski, G.M., Schnoor, J.L., Youngman, A., Licht, L. \& Erickson, L.E. (2002a). Poplar trees for phytostabilization of abandoned zinc-lead smelter, Practice Periodical of Hazardous, Toxic, and Radioactive Waste Management, 6(3), pp. 177-183.

Pierzynski, G.M., Lambert, M., Hetrick, B.A.D., Sweeney, D.W. \& Erickson, L.E. (2002b). Phytostabilization of metal mine mailings using Tall Fescue, Practice Periodical of Hazardous, Toxic, and Radioactive Waste Management, 6(4), pp. 212-217.

Poot, M., Teubert, H., Rabinovitch, P.S. \& Kavanagh, T.J. (1995) De novo synthesis of glutathione is required for both entry into and progression through the cell cycle, Journal of Cellular Physiology, 163, pp. 555-560.

Rauser, W.E. (2000). Roots of maize seedlings retain most of their cadmium through two complexes, Journal of Plant Physiology, 156, pp. 545-551.

Reeves, R.D. \& Brooks, R.R. (1983). Hyperaccumulation of lead and zinc by two metallophytes from a mining area of Central Europe, Environmental Pollution Series A, 31, pp. 277-287.

Robinson, N.J., Tommey, A.M., Kuske, C. \& Jackson, P.J. (1993). Plant metallothioneins, Biochemical Journal, 295, pp. 1-10.

Rock, S. (2003), Field evaluations of phytotechnologies. In: McCutcheon SC, Schnoor JL, Phytoremediation: Transformation and Control of Contaminants. John Wiley and Sons, Inc., New Jersey 2003.

Roosens, N.H.C.J., Willems, G. \& Saumitou-Laprade, P. (2008). Using Arabidopsis to explore zinc tolerance and hyperaccumulation, Trends in Plant Science, 13, pp. 208-215.

Singla-Pareek, S.L., Yadav, S.K., Pareek, A., Reddy, M.K. \& Sopory, S.K. (2006). Transgenic tobacco overexpressing glyoxalase pathway enzymes grow and set viable seeds in zinc-spiked soils, Plant Physiology, 140, pp. 613-623.

Siwek, M. (2008a). Plants in industrial environment contaminated with heavy metals. Part II. Mechanisms of detoxication and adaptation strategies to high concentrations of heavy metals , Wiadomości Botaniczne, 52 (3/4), pp. 7-23. (in Polish)

Siwek, M. (2008b). Plants in industrial environment contaminated with heavy metals. Part I. Uptake, transport and toxicity of trace heavy metals, Wiadomości Botaniczne, $52(1 / 2)$, pp. 7-22. (in Polish)

de Souza, M.P., Chu, D., Zhao, M., Zayed, A.M., Ruzin, S.E., Schichnes, D. \& Terry, N. (1999). Rhizosphere bacteria enhance selenium accumulation and volatilization by Indian mustard, Plant Physiology, 119 (2), pp. 565-573.

Tam, P.C.F. (1995). Heavy metal tolerance by ectomycorrhyzal fungi and metal amelioration by Pisolithus tinctorium, Mycorrhiza, 5 (3), pp. 181-187.

Tomović, G.M., Nevena Lj. Mihailović, N.Lj., Tumi, A.F., Gajić, B., Mišljenović T.D., Niketić, M.S. (2013). Trace metals in soils and several Brassicaceae plant Species from serpentine sites of Serbia, Archives of Environmental Protection, 39(4), pp. $29-49$.

Turnau, K., Jurkiewicz, A. \& Grzybowska, B. (2002). The role of miccorhizae in bioremediation of contaminated areas, Kosmos, 51 (2), pp. 185-194. (in Polish)

Turnau, K. \& Mesjasz-Przybyłowicz, J. (2003). Arbuscular mycorrhizal fungi diversity in the rhizosphere of Viola 
calaminaria and effect of these fungi on heavy metal uptake by clover, Mycorrhiza, 10, pp. 161-168.

US EPA (2001). Phytoextraction of lead in soils at Magic Marker and Ft. Dix. Innovative Technology Evaluation Report, US EPA. National Risk Management Research Laboratory, Cincinatti 2001.

Verma, P., George, K.V., Singh, H.V., Singh, S.K., Juwarkar, A. \& Singh, R.N. (2006). Modeling rhizofiltration: heavy-metal uptake by plant roots, Environmental Modeling \& Assessment, 11, pp. 387-394.

Wang, J., Zhao, F., Meharg, A.A., Raab, A., Feldmann, J. \& McGrath, P.S. (2002). Mechanisms of arsenic hyperaccumulation in Pteris vittata. Uptake kinetics, interactions with phosphate, and arsenic speciation, Plant Physiology, 130, pp. 1552-1561.

Wong, M.H. \& Bradshaw, A.D. (2002). The restoration and management of derelict land. Modern approaches, World Scientific Publishing, Singapore, Japan 2002.

Wójcik, A. \& Tukiendorf, A. (1995). Strategy of stress avoidance in resistance of plants to heavy metals, Wiadomości Botaniczne, 39 (3/4), pp. 33-40. (in Polish)

Woźny, A. \& Przybył, K. (2004). Plant cells under stress conditions, Wydawnictwo Naukowe PWN, Poland 2004. (in Polish)

Yang, B., Shu, W., Ye, Z., Lan, C. \& Wong, M. (2003). Growth and metal accumulation in vetiver and two Sesbania species on I tailings, Chemosphere, 52, pp. 1593-1600.

Yang, X., Feng, Y., He, Z. \& Stoffella, P.J. (2005). Molecular mechanisms of heavy metal hyper accumulation and phytoremediation, Journal of Trace Elements in Medicine and Biology, 18 (4), pp. 339-353.

Yoon, J., Cao, X. \& Zhou, O. (2006). Accumulation of Pb, Cu, and Zn in native plants growing on a contaminated, Science of the Total Environment, 368, pp. 456-464.

Zayed, A.M., Lytle, C.M. \& Terry, N. (1998). Accumulation and volatilization of different chemical species of selenium by plants, Planta, 206 (2), pp. 284-292.

Zenk, M.H. (1996). Heavy metal detoxification in higher plants - a review, Gene, 179, pp. 21-30.

Zhou, G.K., Xu, Y.F. \& Liu, J.Y. (2005). Characterization of a rice class II metallothionein gene: tissue expression patterns and induction in response to abiotic factors, Science of the Total Environment, 162, pp. 686-696.

Zhu, Y.L., Pilon-Smits, E.A.H., Jouanin, L. \& Terry, N. (1999a). Over expression of glutathione synthetase in Indian mustard enhances cadmium accumulation and tolerance, Plant Physiology, 119, pp. 73-79.

Zhu, Y.L., Pilon-Smits, E.A.H., Tarun, A.S., Weber, S.U., Jouanin, L. \& Terry, N. (1999b). Cadmium tolerance and accumulation in Indian mustard is enhanced by overexpressing - glutamylcysteine synthatase, Plant Physiology, 121, pp. 1169-1177.

Zimeri, A.M., Dhankher, O.M., McCaig, B. \& Meagher, R.B. (2005). The plant MT1 metallothioneins are stabilized by binding cadmium and are required for cadmium tolerance and accumulation, Plant Molecular Biology, 58, pp. 839-855.

\section{Mechanizmy unikania i tolerowania stresu przez rośliny używane w fitoremediacji metali ciężkich}

Streszczenie: Zanieczyszczenie gleb metalami ciężkimi jest poważnym problemem środowiska naturalnego, ponieważ ma negatywny wpływ m.in. na zdrowie ludzi i rolnictwo. Fitoremediacja może być alternatywną technologią oczyszczania środowiska, wykorzystującą naturalną zdolność roślin do pobierania, gromadzenia lub przekształcania zanieczyszczeń. Dla zapewnienia prawidłowego wzrostu i rozwoju roślinom na terenach zanieczyszczonych (np. przez metale ciężkie) konieczne jest wykształcenie przez rośliny odpowiednich mechanizmów ochronnych przed toksycznym działaniem tych zanieczyszczeń. W artykule przedstawiono przegląd najważniejszych fizjologicznych mechanizmów unikania stresu i tolerancji przez rośliny wykorzystywane w fitoremediacji metali ciężkich. 